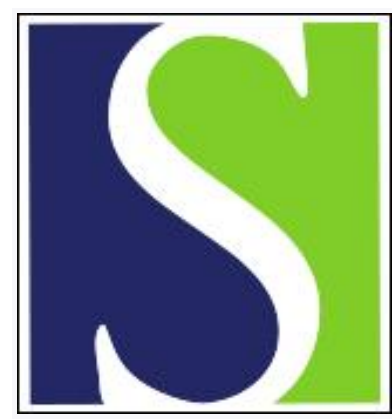

Scand J Work Environ Health 2013;39(2):178-186

https://doi.org/10.5271/sjweh.3299

Published online: 19 Apr 2012, Issue date: 01 Mar 2013

Rotating night shift work and polymorphism of genes important for the regulation of circadian rhythm

by Reszka E, Peplonska B, Wieczorek E, Sobala W, Bukowska A, Gromadzińska J, Lie J-A, Kjuus H, Wasowicz W

Affiliation: Department of Toxicology and Carcinogenesis, Nofer Institute of Occupational Medicine, 8 Teresy Street, 91-348 Lodz, Poland. edyta@imp.lodz.pl

Key terms: cancer; chronotype; circadian rhythm; gene; night shift work; night work; nurse; polymorphism; rotating shift; shift work; shift worker; sleep

This article in PubMed: www.ncbi.nlm.nih.gov/pubmed/22517501

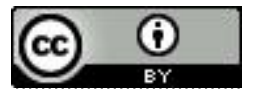




\title{
Rotating night shift work and polymorphism of genes important for the regulation of circadian rhythm
}

\author{
by Edyta Reszka, PhD, ${ }^{1}$ Beata Peplonska, MD, PhD, ${ }^{2}$ Edyta Wieczorek, MSc, ${ }^{1}$ Wojciech Sobala, MSc, ${ }^{2}$ \\ Agnieszka Bukowska, MSc, ${ }^{2}$ Jolanta Gromadzinska, PhD, ${ }^{1}$ Jenny-Anne Lie, PhD, ${ }^{3}$ Helge Kjuus, MD, PhD, ${ }^{3}$ \\ Wojciech Wasowicz, PhD ${ }^{1}$
}

Reszka E, Peplonska B, Wieczorek E, Sobala W, Bukowska A, Gromadzinska J, Lie J-A, Kjuus H, Wasowicz W. Rotating night shift work and polymorphism of genes important for the regulation of circadian rhythm. Scand $J$ Work Environ Health. 2013;39(2):178-186. doi:10.5271/sjweh.3299

\begin{abstract}
Objective People living in industrialized societies have developed specific working schedules during the day and at night, including permanent night shifts and rotating night shifts. The aim of this study was to examine the association between circadian polymorphisms and rotating night shift work.
\end{abstract}

Methods This cross-sectional study comprised 709 nurses and midwives ( 348 current rotating and 361 current day workers). Genetic polymorphism of selected clock genes BMAL1 (rs2279287), CLOCK (rs1801260), PER1 (rs2735611), PER2 (rs2304672), PER3 (rs10462020), CRY1 (rs8192440), CRY2 (rs10838527, rs10838527) was determined using real-time polymerase chain reaction (PCR) assays.

Results There were no differences in BMAL1, CLOCK, CRY2, PER1, PER2, and PER3 genotypes among nurses and midwives working rotating night and day shifts. The frequency of women with rare CRY1 TT genotype was higher in the group of rotating night shift than day workers $(17.0 \%$ versus $13.9 \%, \mathrm{P}=0.06)$. Moreover, $C R Y 1 \mathrm{TT}$ genotype was associated with the total rotating shift work duration, compared to women rarely working night shifts.

Conclusions These results suggest that CRY1 (rs8192440) polymorphism may influence the adaptation to the rotating night shift work among nurses and midwives.

Key terms cancer; chronotype; night work; nurse; rotating shift; shift worker; sleep.

The endogenous and self-sustained circadian rhythm in humans can coordinate various molecular, biochemical, and physiological processes in response to environmental light and temperature changes during the day and the season, resulting in the adaptation of sleep-wake cycles, body temperature, energy metabolism, cell cycle, hormone secretion etc. (1). It has been suggested that disturbances of 24-hour sleep-wake rhythms, including shift work, may cause various reversible health problems such as insomnia, fatigue, and mood and appetite fluctuations (2). Moreover, shift work that involves circadian disruption has been classified by the International Agency for Research on Cancer as a probable human carcinogen, group 2A, based on limited evidence of carcinogenicity in humans and sufficient evidence of carcinogenicity in experimental animals (3). As suggested, the disruption of the circadian cycle may be related to the etiology of hormone-related female breast cancer, due to alteration of melatonin synthesis in pineal gland (4) and also in connection with the alterations of the circadian gene expression (5).

The biological molecular clock is controlled by several genes forming autoregulatory transcriptional and translational feedback loops with both positive and negative elements (6). Moreover, the transcription-translation feedback loops of circadian genes may control the expression of a variety of genes involved in different biological processes (7). Micro array studies have shown that up to $10 \%$ of mammalian transcriptome in specific tissues (up to $50 \%$ in the liver) presents the circadian regulation $(8,9)$. It has been suggested that circadian genes may be involved in cell proliferation, apoptosis, cell cycle control, DNA damage repair, chromatin remodeling, and

1 Department of Toxicology and Carcinogenesis, Nofer Institute of Occupational Medicine, Lodz, Poland.

2 Department of Environmental Epidemiology, Nofer Institute of Occupational Medicine, Lodz, Poland.

3 National Institute of Occupational Health, Oslo, Norway.

Correspondence to: Edyta Reszka, Department of Toxicology and Carcinogenesis, Nofer Institute of Occupational Medicine, 8 Teresy Street, 91-348 Lodz, Poland. [E-mail: edyta@imp.lodz.pl] 
cell signaling, and, therefore, their function is related to tumor suppressors (10). The area of interest in the biological clock alterations and their impact on cancer has been focused on several (at least 18 known) circadian genes: aryl hydrocarbon receptor nuclear translocator-like (ARNTL or BMAL1), ARNTL2, CLOCK, cryptochrome 1 (CRY1), CRY2, Period1 (PER1), PER2, PER3, casein kinase 1, epsilon (CSNK1E) and delta (CSNK1D), neuronal PAS domain protein 2 (NPAS2), basic helix-loop-helix family, member e40 (BHLHE40) and e41 (BHLHE41), nuclear receptor subfamily 1, group D (NR1D1), RARrelated orphan receptor $A$ and others, that might modulate the susceptibility of individuals to the chronodisruption effects $(10,11)$.

Shift workers may have disrupted circadian rhythm because of exposure to light at night during the working hours. The majority of association studies have indicated that polymorphisms in circadian genes among humans were implicated in diurnal preference and seasonality, psychobehavioral factors and mental disorders, obesity, metabolic syndrome, hypertension, type 2 diabetes and cancer (12). On the other hand, the question "How do shift working people develop different adaptation mechanisms in their sleep-wake cycle?" seems to be very important for public health. It appears that a complete circadian rhythm adjustment is seldom achieved and only a minority of night shift workers may adapt their internal circadian clock to the nocturnal activity pattern (13). So far, only a few studies have investigated the association between night shift work and circadian rhythm polymorphism $(14,15)$. There is still lack of knowledge regarding the impact of circadian gene variants on the night shift work adaptation, and on the effect of exposure to light during the night working hours (1).

We have undertaken this cross-sectional study of nurses and midwives currently working different schedules to investigate if polymorphism of seven selected core circadian genes [BMAL1, CLOCK (positive regulators of circadian rhythm), CRY1, CRY2, PER1, PER2, PER3 (negative regulators of circadian rhythm)] contributes to rotating night shift work adaptive mechanism, also in relation to diurnal preferences.

\section{Methods}

\section{Study design}

The cross-sectional study was conducted among nurses selected from the Local Registry of the Chamber of Nurses and Midwives in Lodz. The questionnaire data and biological samples were collected in 2008-2010 (16). The inclusion criteria for the nurses were age 40-60 years and current employment. The study par- ticipants completed a structured questionnaire during an in-person interview that provided information on occupational history, demographic characteristics, medical and reproductive history, physical activity [according to the International Questionnaire on Physical Activity (IPAQ)], sleep quality (according to the Pittsburgh Sleep Quality Index) (17), morning- and evening-typeness (according to self-reported preference and a question regarding "lark" or "owl" personality with the explanation of the terms), smoking, and alcohol use (table 1).

The occupational data included information on the current and previous jobs. We calculated the lifetime total duration of night shift work. The average frequency of the night shifts at the current job was analyzed in two categories: 1-7 and $\geq 8$ nights per month. Additionally, we used the data from a diary that the nurses completed during the week preceding the blood collection, with two categories formed and analyzed: $1-2$ and $\geq 3$ night shifts during the week.

Blood samples were collected into S-Monovette ${ }^{\circledR}$ heparinized test tubes in the morning (06:00-10:00 hours). At the end of the night shift, blood samples were collected from rotating night shift women, while samples were collected at the beginning of work from daytime working nurses.

The Ethics Committee for Scientific Research at the Nofer Institute approved the study protocol, and a written informed consent was obtained from each woman before participation in the study.

\section{Genotyping}

Blood samples were preserved immediately after delivery to the lab and stored at $-20{ }^{\circ} \mathrm{C}$ until DNA isolation. Genomic DNA was isolated from 709 samples of the whole blood using QIAamp DNA Blood Mini Kit (Qiagen GmbH, Hilden, Germany), according to the manufacturer's instructions. Primers and probes for high-resolution-melt (HRM) and restriction fragment length polymorphism-polymerase chain reaction (RFLPPCR) assays were designed with Beacon Designer 7.01 (PREMIER Biosoft International, Palo Alto, CA, USA) according to the GenBank ${ }^{\circledR}$ genetic sequence database, and genetic polymorphism was analyzed using real-time PCR assay. Single nucleotide polymorphisms (SNP) of circadian genes were selected based on position within the gene, predicted function and minor allele frequency, according to the SNP database in the National Center for Biotechnology Information (CRY1, CRY2) (18) and on the basis of relevant literature (BMAL1, CLOCK, PER1, PER2, PER3) (19-23) (table 2). Allelic discrimination for PER1 (rs2735611), PER2 (rs2304672), PER3 (rs10462020), CRY2 (rs10838524), CRY2 (rs10838527) was analyzed and TaqMan ${ }^{\circledR}$ pre-design SNP assays and TaqMan® Genotyping Master Mix (Life Technologies 
Table 1. Selected characteristics of nurses and midwives in the cross-sectional study. [BMI=body mass index; SD=standard deviation; $\mathrm{PSQ}=$ Pittsburgh sleep quality index; MET= metabolic equivalents of task]

\begin{tabular}{|c|c|c|c|c|c|c|c|c|c|}
\hline & \multicolumn{4}{|c|}{ Day workers $(\mathrm{N}=361)$} & \multicolumn{4}{|c|}{ Rotating shift workers (N=348) } & \multirow[t]{2}{*}{ P-value } \\
\hline & Mean & SD & $\mathrm{N}$ & $\%$ & Mean & SD & $\mathrm{N}$ & $\%$ & \\
\hline Age (years) & 50.2 & 5.3 & & & 48.3 & 5.2 & & & $<0.0001$ \\
\hline BMI $\left(\mathrm{kg} / \mathrm{m}^{2}\right)$ & 27.0 & 4.7 & & & 27.1 & 4.7 & & & 0.98 \\
\hline Job duration (years) & 29.2 & 6.3 & & & 27.4 & 6.6 & & & $<0.0001$ \\
\hline Total night shifts work (years) & 12.4 & 8.3 & & & 26.7 & 7.2 & & & $<0.0001$ \\
\hline \multicolumn{10}{|l|}{ Total night shifts work (categories) } \\
\hline$<5$ years & & & 69 & 19.1 & & & 1 & 0.3 & $<0.0001$ \\
\hline $6-15$ years & & & 165 & 45.7 & & & 22 & 6.3 & \\
\hline$>15$ years & & & 127 & 35.2 & & & 325 & 93.4 & \\
\hline \multicolumn{10}{|c|}{ Time since quitting night shift work (years) a } \\
\hline$<5$ years & & & 59 & 16.8 & & & & & \\
\hline $6-15$ years & & & 87 & 24.8 & & & & & \\
\hline$>15$ years & & & 205 & 57.4 & & & & & \\
\hline Quality of sleep (PSQI score) b & 6.8 & 3.6 & & & 6.4 & 3.0 & & & 0.09 \\
\hline $3-4$ & & & 11 & 3.5 & & & 27 & 8.8 & \\
\hline Physical activity (MET hours per week) & 202.5 & 88.1 & & & 241.4 & 78.4 & & & $<0.0001$ \\
\hline \multicolumn{10}{|l|}{ Chronotype } \\
\hline Morning type & & & 192 & 53.5 & & & 178 & 51.2 & 0.54 \\
\hline Evening type & & & 167 & 46.5 & & & 170 & 48.8 & \\
\hline \multicolumn{10}{|l|}{ Menopausal status } \\
\hline Premenopause & & & 186 & 51.5 & & & 229 & 65.8 & $<0.0001$ \\
\hline Postmenopause & & & 175 & 48.5 & & & 119 & 34.2 & \\
\hline \multicolumn{10}{|l|}{ Smoking } \\
\hline Never smokers & & & 155 & 43.0 & & & 146 & 41.9 & 0.03 \\
\hline Past smokers & & & 110 & 30.5 & & & 81 & 23.3 & \\
\hline Current smokers & & & 96 & 26.6 & & & 121 & 34.8 & \\
\hline \multicolumn{10}{|l|}{ Alcohol consumption } \\
\hline No & & & 333 & 92.2 & & & 323 & 92.8 & 0.77 \\
\hline Yes & & & 28 & 7.7 & & & 25 & 7.2 & \\
\hline \multicolumn{10}{|l|}{ Antidepressants use } \\
\hline Yes & & & 342 & 94.7 & & & 334 & 96.0 & 0.43 \\
\hline No & & & 19 & 5.3 & & & 14 & 4.0 & \\
\hline \multicolumn{10}{|l|}{ Marital status } \\
\hline Married & & & 270 & 74.8 & & & 268 & 77.0 & 0.66 \\
\hline Single & & & 16 & 4.4 & & & 19 & 5.5 & \\
\hline Divorced/separated & & & 52 & 14.4 & & & 44 & 12.6 & \\
\hline Widow & & & 23 & 6.4 & & & 17 & 4.9 & \\
\hline \multicolumn{10}{|l|}{ Number of full-term births } \\
\hline 1 & & & 126 & 40.0 & & & 109 & 35.6 & 0.02 \\
\hline 2 & & & 178 & 56.5 & & & 170 & 55.6 & \\
\hline \multicolumn{10}{|l|}{ Blood sampling } \\
\hline March-September & & & 181 & 50.1 & & & 211 & 60.6 & 0.005 \\
\hline October-February & & & 180 & 49.9 & & & 137 & 39.4 & \\
\hline
\end{tabular}

a Missing time since quitting night shift work for 10 day shift women.

${ }^{\mathrm{b}}$ Missing quality of sleep data for 2 day shift women.

Corp, Grand Island, NY, USA) and BMAL1 (rs2279287), CLOCK (rs801260), CRY1 (rs8192440) genotypes were analyzed with HRM assay and SsoFastTM EvaGreen ${ }^{\circledR}$ Supermix (Bio-Rad Laboratories, Inc, Hercules, CA, USA). The analyzed genotypes were verified by means of RFLP-PCR assays with specific endonucleases, except for PER1 and PER2 SNP. Genotyping was performed using control DNA samples with known genotypes and a negative control. Samples with ambiguous results were retested and approximately $15 \%$ of all tests were repeated.

\section{Statistical analysis}

Arithmetic means with standard deviations and frequen- cies of the basic characteristics were calculated. The linear regression was used to compare means of the continuous variables, and the Pearson Chi-square test was calculated to compare the frequencies distribution among women working on rotating night shifts and day workers. A Chi-square test was used to determine any discrepancies of distribution from Hardy-Weinberg Equilibrium (HWE). The associations between circadian gene polymorphism and rotating night shift work parameters were computed by logistic or multinomial regression. The associations with total duration of night shift work were analyzed using linear regression. To adjust for factors that may influence genotypes distribution, we formulated a list of potential confounders. The list included age, body mass 
Table 2. Circadian genes single nucleotide polymorphisms analyzed in the cross-sectional study of nurses and midwives. [SNP=single nucleotide polymorphisms; mRNA=messenger ribonucleic acid; $N A=$ not available; Ref=reference]

\begin{tabular}{|c|c|c|c|c|c|c|c|c|c|}
\hline Gene & SNP ID & Chromosome & $\begin{array}{c}\text { mRNA } \\
\text { position }\end{array}$ & Protein residues & Region & $\begin{array}{l}\text { Major } \\
\text { allele (1) }\end{array}$ & $\begin{array}{l}\text { Minor } \\
\text { allele (2) }\end{array}$ & $\begin{array}{l}\text { Minor allele } \\
\text { frequency b }\end{array}$ & Ref \\
\hline$B M A L 1^{\text {a }}$ & rs2279287 & $11 \mathrm{p} 15$ & $N A$ & & 5'UTR & C & $\mathrm{T}$ & 0.37 & 23 \\
\hline CLOCK & rs1801260 & $4 q 12$ & 3680 & & 3'UTR & $\mathrm{T}$ & C & 0.32 & 22 \\
\hline PER1 & rs2735611 & 17p13.1-17p12 & 2485 & Gly749Gly & Exon 18 & C & $\mathrm{T}$ & 0.14 & 20 \\
\hline PER2 & rs2304672 & $2 q 37.3$ & 226 & & 5'UTR & C & G & 0.14 & 19 \\
\hline PER3 & rs10462020 & $1 p 23.23$ & 2091 & Val639Gly & Exon 15 & $\mathrm{~T}$ & G & 0.20 & 21 \\
\hline CRY1 & rs8192440 & $12 q 23-q 24.1$ & 1532 & Gly212Gly & Exon 5 & C & $\mathrm{T}$ & 0.40 & 18 \\
\hline CRY2 & rs10838524 & $11 p 11.2$ & NA & & Intron 1 & $A$ & G & 0.48 & 18 \\
\hline CRY2 & rs10838527 & $11 \mathrm{p} 11.2$ & 2599 & & 3'UTR & A & G & 0.08 & 18 \\
\hline
\end{tabular}

a Frequency not in Hardy-Weinberg equilibrium.

${ }^{b}$ Frequency in total group of nurses and midwives $(\mathrm{N}=709)$.

index (BMI), alcohol drinking (drinks per week), antidepressants use and chronotype. Only age and BMI were significantly associated with genotypes distribution and night shift work status and were included in the models. To investigate potential modification of the associations between night shift work and genotypes by chronotype, we performed stratified analyses in the strata (morningand evening-type persons). Modification of the effect was tested using likelihood ratio test comparing appropriate likelihood statistics between models with and without interaction terms.

Moreover, we investigated initial selection after start of night shift work using Cox regression - with the Breslow method for ties. We used period of first five years in analysis of relationship between polymorphisms and selection out of shift work.

The value of $\mathrm{P}<0.05$ for group characteristics was considered to represent statistical significance, and the statistical tests were two-sided. To account for multiple comparison (eight polymorphisms), we applied the Bonferroni correction method with significance level of $\mathrm{P}<0.05 / 8=0.00625$.

Statistical analyses were performed with STATA11 (StataCorp, College Station, TX, USA) software.

\section{Results}

The selected characteristics of the study population are presented in table 1 . The investigated nurses, 348 current rotating shift workers and 361 current day workers differed significantly for age $(\mathrm{P}<0.0001)$, menopausal status $(\mathrm{P}<0.0001)$, and the number of full-term births $(\mathrm{P}=0.05)$. Current smoking was more frequent among nurses working rotating night shifts than women working day shifts $(\mathrm{P}=0.02)$. There were no differences between the groups concerning the BMI and the quality of sleep. The physical activity of night shift nurses was significantly higher than among daytime working women $(\mathrm{P}<0.0001)$. In both groups, the frequency of morning- and evening-types was similar.

The average total work duration was significantly shorter (27.5 years) among nurses currently working rotating night shifts than day workers (29.2 years). The mean duration of night shift work among women currently working rotating shifts was 26.6 years. Dayshift women had worked night shifts in the past with an average duration of 12.4 years. Of the women currently working day shifts, $35 \%$ had previously worked $>15$ years on a rotating night shift schedule, while $19 \%$ of the day-shift women had previously worked $<5$ years on that schedule (table 1).

The nurses working rotating night shifts in our study had been working 12-hour shifts, from 19:00-07:00 hours. They reported working $2-14$ nights per month, $\leq 4$ nights per week and $\leq 3$ consecutive nights. The majority of the rotating-shift nurses worked on average 2-7 nights per month, 2 nights per week without any consecutive nights (data not shown). Rotating night shift work duration was negatively correlated with the age of the nurses ( $\beta$-coefficient $=-1.87, \mathrm{P}<0.0001$ ) (data not shown).

All SNP were in HWE, except from BMAL1 $(\mathrm{P}<0.01)$. The prevalence of minor allele CRY2 (rs10838524) was highest (0.48) and lowest in CRY2 (rs10838527) (0.08). Minor allele frequencies in the total analyzed group $(\mathrm{N}=709)$ are presented in table 2. There were no differences in BMAL1 (rs2279287), CLOCK (rs1801260), CRY1 (rs8192440), CRY2 (rs10838524, rs10838527), PER1 (rs2735611), PER2 (rs2304672), PER3 (rs10462020) genotype distribution among women working in the system of rotating night shifts and day shifts (table 3). Subjects with rare CRYI TT genotype were more frequent among nurses and midwives working rotating night shifts than day shift workers $(17.0 \%$ versus $13.9 \%)$ (table 3). CRY1 TT genotype was associated with long total duration of rotating night shift work. It was more frequent among women who reported working on average $\geq 8$ nights during the month and $\geq 3$ nights during the preceding week (tables $4 \mathrm{a}, \mathrm{b}$ and $\mathrm{c}$ ) compared to women 
Table 3. Circadian genotype frequencies among nurses and midwives in the cross-sectional study.

\begin{tabular}{|c|c|c|c|c|c|c|c|c|c|c|}
\hline & \multicolumn{2}{|c|}{$11^{\mathrm{a}}$} & \multicolumn{2}{|c|}{$12^{a}$} & \multicolumn{2}{|c|}{$22^{\text {a }}$} & \multirow[t]{2}{*}{$\mathrm{P}$-value ${ }^{\mathrm{b}}$} & \multicolumn{2}{|c|}{$12+22^{a}$} & \multirow[t]{2}{*}{ P-value ${ }^{c}$} \\
\hline & $\mathrm{N}$ & $\%$ & $\mathrm{~N}$ & $\%$ & $\mathrm{~N}$ & $\%$ & & $\mathrm{~N}$ & $\%$ & \\
\hline \multicolumn{11}{|c|}{$B M A L 1$ rs2279287 } \\
\hline Day & 156 & 43.2 & 147 & 40.7 & 58 & 16.1 & \multirow[t]{2}{*}{0.63} & 205 & 56.8 & \multirow[t]{2}{*}{0.34} \\
\hline Rotating & 146 & 42.0 & 148 & 42.5 & 54 & 15.5 & & 202 & 58.0 & \\
\hline \multicolumn{11}{|c|}{ CLOCK rs1801260 } \\
\hline Day & 158 & 43.8 & 170 & 47.1 & 33 & 9.1 & \multirow[t]{2}{*}{0.63} & 203 & 56.2 & \multirow[t]{2}{*}{0.38} \\
\hline Rotating & 164 & 47.1 & 149 & 42.8 & 35 & 10.1 & & 184 & 52.9 & \\
\hline \multicolumn{11}{|c|}{ PER1 rs2735611 } \\
\hline Day & 272 & 75.3 & 83 & 23.0 & 6 & 1.7 & \multirow[t]{2}{*}{0.44} & 89 & 24.7 & \multirow[t]{2}{*}{0.24} \\
\hline Rotating & 249 & 71.6 & 94 & 27.0 & 5 & 1.4 & & 99 & 28.4 & \\
\hline \multicolumn{11}{|c|}{ PER2 rs2304672 } \\
\hline Day & 268 & 74.2 & 84 & 23.3 & 9 & 2.5 & \multirow[t]{2}{*}{0.90} & 93 & 25.8 & \multirow[t]{2}{*}{0.82} \\
\hline Rotating & 256 & 73.6 & 85 & 24.4 & 7 & 2.0 & & 92 & 26.4 & \\
\hline \multicolumn{11}{|c|}{ PER3 rs 10462020} \\
\hline Day & 224 & 62.0 & 120 & 33.2 & 17 & 4.7 & \multirow[t]{2}{*}{0.37} & 137 & 38.0 & \multirow[t]{2}{*}{0.42} \\
\hline Rotating & 227 & 65.2 & 112 & 32.2 & 9 & 2.6 & & 121 & 34.8 & \\
\hline \multicolumn{11}{|c|}{ CRY1 rs8192440 } \\
\hline Day & 143 & 39.6 & 168 & 46.5 & 50 & 13.9 & \multirow[t]{2}{*}{$0.14^{d}$} & 218 & 60.4 & \multirow[t]{2}{*}{0.08} \\
\hline Rotating & 113 & 32.5 & 176 & 50.6 & 59 & 17.0 & & 235 & 67.5 & \\
\hline \multicolumn{11}{|c|}{ CRY2 rs10838524 } \\
\hline Day & 98 & 27.1 & 189 & 52.4 & 74 & 20.5 & \multirow[t]{2}{*}{0.52} & 263 & 72.9 & \multirow[t]{2}{*}{0.38} \\
\hline Rotating & 83 & 23.9 & 184 & 52.9 & 81 & 23.3 & & 265 & 76.1 & \\
\hline \multicolumn{11}{|c|}{ CRY2 rs10838527 } \\
\hline Day & 298 & 82.5 & 63 & 17.5 & 0 & & \multirow[t]{2}{*}{0.29} & 63 & 17.5 & \multirow[t]{2}{*}{0.34} \\
\hline Rotating & 294 & 84.5 & 53 & 15.2 & 1 & 0.3 & & 54 & 15.5 & \\
\hline
\end{tabular}

a 11-major homozygote, 22-minor homozygote, 12-heterozygote. For genotype decoding see table 2.

${ }^{b}$ Wald-type test based on logistic regression with age as covariate.

c Age-adjusted compared to 11 genotype.

d Age-adjusted $C R Y 1 C T$ versus $C R Y 1 C C, \mathrm{P}=0.18 ; C R Y 1$ TT versus $C R Y 1 C C, \mathrm{P}=0.06$.

Table 4a. CRY1 (rs8192440) polymorphism and total shift work duration, current average night shift work frequency per month and night shifts during the week preceding the blood samples collection. [SD=standard deviation; Ref=reference]

\begin{tabular}{llllcc}
\hline & \multicolumn{5}{c}{ Total night shift work duration (years) } \\
\cline { 2 - 6 } & Mean & SD & Range & Coefficient & P-value ${ }^{a}$ \\
\cline { 2 - 6 } CRY1 CC & 28.5 & 6.6 & $4.5-42.8$ & Ref & 0.12 \\
CRY1 CT & 28.1 & 6.3 & $8.0-43.4$ & -0.15 & \\
CRY1 TT & 29.0 & 7.1 & $7.3-42.8$ & 2.15 & \\
\hline
\end{tabular}

a Wald test based on linear regression with age and body mass index as covariates; $C R Y 1$ CT versus $C R Y 1 \mathrm{CC}, \mathrm{P}=0.87$; $C R Y 1$ TT versus $C R Y 1$ $\mathrm{CC}, \mathrm{P}=0.07$.

Table 4b. CRY1 (rs8192440) polymorphism and total shift work duration, current average night shift work frequency per month and night shifts during the week preceding the blood samples collection. [RRR=relative risk ratio; Ref=reference]

\begin{tabular}{|c|c|c|c|c|c|c|c|c|c|}
\hline & \multicolumn{9}{|c|}{ Average night shift work frequency per month } \\
\hline & \multicolumn{2}{|c|}{ Day } & \multicolumn{2}{|c|}{$\begin{array}{c}1-7 \\
\text { nights }\end{array}$} & \multicolumn{2}{|c|}{$\begin{array}{c}\geq 8 \\
\text { nights }\end{array}$} & \multirow[t]{2}{*}{$\begin{array}{c}\mathrm{P}- \\
\text { value a }\end{array}$} & \multirow{2}{*}{$\begin{array}{c}\geq 8 \text { ver- } \\
\text { sus } 1-7 \\
\text { nights } \\
\text { RRR }\end{array}$} & \multirow[t]{2}{*}{$\begin{array}{c}\mathrm{P}- \\
\text { value }\end{array}$} \\
\hline & $\mathrm{N}$ & $\%$ & $\mathrm{~N}$ & $\%$ & $\mathrm{~N}$ & $\%$ & & & \\
\hline CRY1 CC & 143 & 39.7 & 102 & 32.9 & 11 & 28.2 & 0.03 & Ref & 0.04 \\
\hline CRY1 CT & 167 & 46.4 & 162 & 52.3 & 15 & 38.5 & & 0.89 & \\
\hline CRY1 TT & 50 & 13.9 & 46 & 14.8 & 13 & 33.3 & & 2.42 & \\
\hline
\end{tabular}

Table 4c. CRY1 (rs8192440) polymorphism and total shift work duration, current average night shift work frequency per month and night shifts during the week preceding the blood samples collection. [RRR=relative risk ratio; Ref=reference]

\begin{tabular}{|c|c|c|c|c|c|c|c|c|c|}
\hline & \multicolumn{9}{|c|}{ Night shifts during the preceding week } \\
\hline & \multicolumn{2}{|c|}{ Day } & \multicolumn{2}{|c|}{$\begin{array}{c}1-2 \\
\text { nights }\end{array}$} & \multicolumn{2}{|c|}{$\begin{array}{c}\geq 3 \\
\text { nights }\end{array}$} & \multirow[t]{2}{*}{$\begin{array}{c}\text { P- } \\
\text { value }^{a}\end{array}$} & \multirow{2}{*}{$\begin{array}{c}\geq 3 \text { versus } \\
1-2 \text { nights } \\
R R R\end{array}$} & \multirow[t]{2}{*}{$\begin{array}{c}P- \\
\text { value }\end{array}$} \\
\hline & $\mathrm{N}$ & $\%$ & $\mathrm{~N}$ & $\%$ & $\mathrm{~N}$ & $\%$ & & & \\
\hline CRY1 CC & 146 & 40.1 & 96 & 33.2 & 14 & 25.5 & 0.09 & Ref & 0.17 \\
\hline CRY1 CT & 168 & 46.2 & 149 & 51.6 & 27 & 49.1 & & 1.22 & \\
\hline CRY1 TT & 50 & 13.7 & 44 & 15.2 & 14 & 25.5 & & 2.14 & \\
\hline
\end{tabular}

age-adjusted wald test based on multinomial regression with age and body mass index (BMI) as covariates.

b Wald test based on multinomial regression with age and BMI as covariates; $C R Y 1 \mathrm{CT}$ versus $C R Y 1 \mathrm{CC}, \mathrm{P}=0.78 ; \mathrm{CRY1}$ TT versus $C R Y 1 \mathrm{CC}, \mathrm{P}=0.05$.

working rarely at night. PER1 (rs2735611) and PER3 (rs10462020) polymorphisms were also associated with a high number of night shifts per week as reported in the diaries. We found a higher frequency of rare PERI TT or rare $P E R 3 \mathrm{GG}$ homozygotes among nurses who worked $\geq 3$ nights compared to women who worked 1 or 2 nights during the preceding week (5.7\% versus $0.7 \%$ and $5.7 \%$ versus $2.1 \%$, respectively). However, the number of individuals in each genotype group was relatively small ( 3 versus 2 and 3 versus 6 , respectively) (data not shown). 
The likelihood of resigning from night shift work in the first 5 years was lower among nurses and midwives who started their job with rotating night shift schedule and who were carriers of $\geq 1$ minor PER1 T allele [hazard ratio (HR) $0.74,95 \%$ confidence interval $(95 \% \mathrm{CI}) 0.56-0.99$, $\mathrm{P}=0.04]$ or $\geq 1$ minor $C R Y 2 \mathrm{G}$ allele (rs10838527) (HR $0.66,95 \%$ CI $0.46-0.95, \mathrm{P}=0.03$ ) than among women with common genotype (data not shown).

There were no differences in circadian genotype distribution in relation to the chronotype of nurses and midwives. Individuals with $\geq 1$ minor $C R Y 1 \mathrm{~T}$ allele were observed more frequently among morning- than evening-types (67.6\% versus 59.9\%) (table 5). We observed modification of the association between night shift work and CRY1 genotype by chronotype (P-value for heterogeneity $=0.017$ ). No difference in the distribution of $C R Y 1$ polymorphism by system of work was found among the morning-type women, while frequencies of specific genotypes differed among the evening-type women. Among evening-types, CRY1 TT genotype was $>2$-fold frequent [odds ratio (OR) 2.6, 95\% CI1.3-5.1], while CRY1 CT genotype was approximately 1.5 -fold frequent (OR 1.6, 95\% CI1.0-2.6) among the rotating nigh nurses when compared to day nurses (table 6).

\section{Discussion}

People living in industrialized societies have developed specific working schedules during the day and at night, including permanent and rotating night shifts. Light at night may disturb the internal clock, with suggested potential health consequences such as cancer, cardiovascular diseases, metabolic syndrome, etc. In response to endogenous circadian clues, people working night shifts develop different adaptation mechanisms in their sleep-wakefulness cycle to sustain the circadian rhythm. The complete circadian adjustment is seldom achieved and only a minority of night shift workers may adapt the internal circadian clock to the nocturnal activity pattern. It has been found that intermediate or slow rotations, rather than permanent night shifts, may lead to major disruptions of the circadian rhythm (13).

In the present cross-sectional study, we analyzed the possible association of circadian polymorphism with the adaptation of circadian clock to shift work schedule. To the best of our knowledge, only a few studies have investigated the association between shift work and circadian rhythm polymorphism $(14,15)$, and there are no studies regarding the role of circadian polymorphism in relation to diurnal preferences in rotating night shift work. The analyzed circadian genes SNP were selected based on position within the gene and predicted function and minor allele frequency. Five SNP (BMAL1,
CLOCK, PER1, PER2, PER3) were selected on the basis of relevant literature (19-23), while CRY1 (rs8192440), CRY2 (rs10833824), CRY2 (rs10838527) had not been studied previously and we selected them according to SNP database in the National Center for Biotechnology Information (18).

We observed that the distributions of BMAL1, CLOCK, PER1, PER2, PER 3 and CRY2 genotypes were similar among day shift and rotating night shift workers. However, individuals with rare CRY1 TT (rs8192440) were more frequent in the rotating night shifts group. Interestingly, we found that nurses and midwives with CRY1 TT minor homozygotes had longer night shift work duration than $C R Y 1 \mathrm{CC}$ major homozygotes. Additionally, this genotype was associated with a higher frequency of night shift work at the current job, as evidenced both by the data collected through the interview and the diary. In our study, we found significant modification of the association between night shift work and $C R Y 1$ genotype by chronotype. Frequency of CRYI TT and CRYI CT genotypes in the rotating night shift women were higher when compared to evening-type day nurses. This finding may indicate that the variant allele may play a role in the night work preference among evening-type persons only. This result has to be interpreted cautiously, since we found that $C R Y 1$ TT genotype had similar frequency among morning- $(15.7 \%)$ and evening-types $(18.2 \%)$ who had worked under rotating night shifts. There was no association between chronotype and status of work and no difference in the CRY1 TT genotype among rotating night shift nurses by their reported chronotype. We used only a crude measure of chronotype, which may have introduced some misclassification, with potential for spurious interaction observed. Future studies with better tools for chronotype determination might clarify further the inferences observed in our study. However, our findings may indicate that women with CRY1 TT genotype may have stronger ability and better adaptation to rotating night shift work when compared to CRYI CC carriers.

The transcriptional and translational feedback loops of the circadian auto-regulation system in the suprachiasmatic nucleus $(\mathrm{SCN})$ and peripheral tissues require positive- and negative-acting circadian genes. Recently, it has been found that especially $C R Y 1$ serves also as a strong repressor of morning-time elements (E-box and E'box) and phase delay in $C R Y 1$ transcription is critical for the mammalian clock function (24). CRY1 may also play an important role in auto regulatory feedback loops of circadian apparatus and, in addition, may influence other key metabolic gene expression patterns (6). Although the investigated SNP in CRY1 gene (rs8192440) is localized in exon 5, it leads to synonymous mutation Gly212Gly. Therefore, the functional significance of this SNP may be associated with the linkage with other SNP localized nearby, taking into account that $C R Y 1$ possesses a very 
Table 5. Circadian genes polymorphism and the chronotype of nurses and midwives in the cross-sectional study.

\begin{tabular}{|c|c|c|c|c|c|c|c|c|c|c|}
\hline & \multicolumn{2}{|c|}{$11^{\mathrm{a}}$} & \multicolumn{2}{|c|}{$12^{a}$} & \multicolumn{2}{|c|}{$22^{\mathrm{a}}$} & \multirow[t]{2}{*}{$P$-value ${ }^{b}$} & \multicolumn{2}{|c|}{$12+22^{\text {a }}$} & \multirow[t]{2}{*}{ P-value ${ }^{b}$} \\
\hline & $\mathrm{N}$ & $\%$ & $\mathrm{~N}$ & $\%$ & $\mathrm{~N}$ & $\%$ & & $\mathrm{~N}$ & $\%$ & \\
\hline \multicolumn{11}{|c|}{ BMAL1 rs2279287 } \\
\hline Morning & 159 & 43.0 & 145 & 39.2 & 66 & 17.8 & \multirow[t]{2}{*}{0.23} & 211 & 57.0 & \multirow[t]{2}{*}{0.89} \\
\hline Evening & 143 & 42.4 & 148 & 43.9 & 46 & 13.7 & & 194 & 57.6 & \\
\hline \multicolumn{11}{|c|}{ CLOCK rs 1801260} \\
\hline Morning & 160 & 43.2 & 174 & 47.0 & 36 & 9.7 & \multirow[t]{2}{*}{0.46} & 210 & 56.8 & \multirow[t]{2}{*}{0.23} \\
\hline Evening & 161 & 47.8 & 144 & 42.7 & 32 & 9.5 & & 176 & 52.2 & \\
\hline \multicolumn{11}{|c|}{ PER1 rs2735611 } \\
\hline Morning & 270 & 73.0 & 94 & 25.4 & 6 & 1.6 & \multirow[t]{2}{*}{0.96} & 100 & 27.0 & \multirow[t]{2}{*}{0.78} \\
\hline Evening & 249 & 73.9 & 83 & 24.6 & 5 & 1.5 & & 88 & 26.1 & \\
\hline \multicolumn{11}{|c|}{ PER2 rs2304672 } \\
\hline Morning & 269 & 72.7 & 90 & 24.3 & 11 & 3.0 & \multirow[t]{2}{*}{0.40} & 101 & 27.3 & \multirow[t]{2}{*}{0.47} \\
\hline Evening & 253 & 75.1 & 79 & 23.4 & 5 & 1.5 & & 84 & 24.9 & \\
\hline \multicolumn{11}{|c|}{ PER3 rs 10462020} \\
\hline Morning & 234 & 63.2 & 123 & 33.2 & 13 & 3.5 & \multirow[t]{2}{*}{0.94} & 136 & 36.8 & \multirow[t]{2}{*}{0.75} \\
\hline Evening & 217 & 64.4 & 108 & 32.1 & 12 & 3.6 & & 120 & 35.6 & \\
\hline \multicolumn{11}{|c|}{ CRY1 rs8192440 } \\
\hline Morning & 120 & 32.4 & 189 & 51.1 & 61 & 16.5 & \multirow[t]{2}{*}{$0.11^{\mathrm{c}}$} & 250 & 67.6 & \multirow[t]{2}{*}{0.04} \\
\hline Evening & 135 & 40.1 & 154 & 45.7 & 48 & 14.2 & & 202 & 59.9 & \\
\hline \multicolumn{11}{|c|}{ CRY2 rs10838524 } \\
\hline Morning & 91 & 24.6 & 189 & 51.1 & 90 & 24.3 & \multirow[t]{2}{*}{0.27} & 279 & 75.4 & \multirow{2}{*}{0.58} \\
\hline Evening & 89 & 26.4 & 183 & 54.3 & 65 & 19.3 & & 248 & 73.6 & \\
\hline \multicolumn{11}{|c|}{ CRY2 rs10838527 } \\
\hline Morning & 305 & 82.4 & 64 & 17.3 & 1 & 0.3 & 0.50 & 65 & 17.6 & 0.45 \\
\hline Evening & 285 & 84.6 & 52 & 15.4 & 0 & & & 52 & 15.4 & \\
\hline
\end{tabular}

a 11-major homozygote, 22-minor homozygote, 12-heterozygote. For genotype decoding see table 2.

${ }^{\mathrm{b}}$ Wald-type test based on logistic regression (crude).

c CRY1 TT versus CRY1 CC, $\mathrm{P}=0.12 ; C R Y 1 \mathrm{CT}$ versus $C R Y 1 \mathrm{CC}, \mathrm{P}=0.05$.

Table 6. CRY1 (rs8192440) polymorphism and the chronotype of nurses and midwives under different work schedules in the crosssectional study. P-value for heterogeneity $=0.017$.

\begin{tabular}{|c|c|c|c|c|c|c|c|c|c|c|}
\hline & \multicolumn{4}{|c|}{ Morning-type } & \multirow[t]{3}{*}{ P-value a } & \multicolumn{4}{|c|}{ Evening-type } & \multirow[t]{3}{*}{ P-value a } \\
\hline & \multicolumn{2}{|c|}{ Day } & \multicolumn{2}{|c|}{ Rotating } & & \multicolumn{2}{|c|}{ Day } & \multicolumn{2}{|c|}{ Rotating } & \\
\hline & $\mathrm{N}$ & $\%$ & $\mathrm{~N}$ & $\%$ & & $\mathrm{~N}$ & $\%$ & $\mathrm{~N}$ & $\%$ & \\
\hline CRY1 CC & 63 & 32.8 & 57 & 32.0 & 0.99 & 79 & $47.3^{b}$ & 56 & 32.9 & 0.01 \\
\hline CRY1 CT & 96 & 50.0 & 93 & 52.3 & & 71 & 42.5 & 83 & $48.8^{b}$ & \\
\hline CRY1 TT & 33 & 17.2 & 28 & 15.7 & & 17 & 10.2 & 31 & $18.2^{\mathrm{b}}$ & \\
\hline CRY1 T & 129 & 67.2 & 121 & 68.0 & 0.96 & 88 & 52.7 & 114 & 67.0 & 0.01 \\
\hline
\end{tabular}

a Wald type test based on logistic regression with age as covariate.

${ }^{b}$ CRY1 CT versus $C R Y 1$ CC, $\mathrm{P}=0.051$; $C R Y 1$ TT versus $C R Y 1 \mathrm{CC}, \mathrm{P}=0.005$.

long sequence, is located on 12q23-24.1, and includes 12 exons. Unfortunately, the comprehensive screening for CRY1 mutations and the linkage disequilibrium analysis has not covered this particular SNP (25). In addition, a recent study on patients suffering bipolar disorder indicates that $C R Y 1 \mathrm{~T}$ minor alleles were nominally associated with good lithium treatment response (26).

Studies on shift workers indicated that $C L O C K$ haplotype formed by rs 1554483 and rs 4864548 SNP modulates the risk of metabolic syndrome among rotating shift workers in Argentina (15), and CLOCK (rs1801260) polymorphism was not associated with night shift work among women in the US (14). To compare, this genetic polymorphism has been correlated with diurnal preferences $(22,27)$. In the Japanese population, individuals with $C L O C K$ CC genotype possessed stronger evening preference, delayed sleep onset, and were characterized by shorter sleep time in comparison to the subjects with minor CLOCK T allele (27). However, studies on various Caucasian populations have not shown any associations between CLOCK polymorphism and diurnal preferences $(28,29)$. The results of the studies on the impact of PERI (rs2735611) polymorphism on diurnal preference are also inconsistent $(20,30)$. PERI T minor alleles were more frequent among subjects with extreme morning-compared to extreme evening-preference in the UK population (20). PER3 (rs10462020) polymorphism was associated with seasonal affective disorder among the US individuals (29). In the cross-sectional study, we observed that among woman with $\geq 1$ PER $1 \mathrm{~T}$ allele who 
started their job with rotating night shift schedule, the likelihood that they would resign from night shift work in the first 5 years was lower than for women with PERI $C C$ genotype. We also observed no association between PER1 or PER3 polymorphism with current work pattern or the chronotype. However, these polymorphisms were associated with the number of night shifts during the preceding week. The majority of minor PERI TT and PER 3 GG homozygotes were found among nurses who worked more intensively on rotating shifts a week before the analysis ( $\geq 3$ nights) than women who worked 1 or 2 nights or who worked only during the day. PER2 SNP (rs2304672) has been linked to diurnal preference and the advanced sleep phase syndrome (19), seasonal variation in mood and winter depression (31), and depression vulnerability (11). The minor PER $2 \mathrm{G}$ alleles frequency were significantly higher among Caucasian subjects with extreme morning-preference than those with extreme evening-preference (19), and in the present cross-sectional study, the prevalence of minor PER $2 \mathrm{G}$ alleles was more frequent in morning- than evening-types. Moreover, we did not find any association between BMAL1 and CRY2 genotypes and rotating shift work or between $B M A L 1$ and $C R Y 2$ genotypes with the chronotype. Among nurses and midwives who started their job with rotating night shift schedule and who had CRY2 (rs10838527) AG and/or GG genotype, the chances that they would resign from night shift work in the first five years were lower than among women with CRY2 AA genotype. Moreover, it was found that $C R Y 2$ (rs10838527 and rs10838524) minor alleles were associated with bipolar disorder (32) and winter depression (33), and BMAL1 (rs2279287) was also associated with bipolar disorder $(23,34)$.

The adaptation to night shift work may be associated with different individual characteristics. For instance, younger age or low scores of morning-typeness have been associated with better night shift work tolerance. However, some studies indicate the opposite association and also a lack of association (1). The strength of this study is that it was conducted in a well-characterized population of women. Several limitations could have affected the results of our cross-sectional study, including insufficient coverage of SNP within circadian genes and the crude measure of diurnal preferences. In addition, the study was underpowered for the assessment of moderate or small effects for minor alleles. However, with this sample size ( $N=709$ ) we had the power of $\geq 90 \%$ to observe associations of the magnitude of OR 2.0 with rare homozygotes with frequency of $10-20 \%$. The present study's findings indicate that rotating night shift work adaptation is not associated with polymorphism of BMAL1, CLOCK, CRY2, PER1, PER2 circadian genes. However, CRY1 (rs8192440) genetic polymorphism may influence the adaptation to rotating night shift work among nurses and midwives. Furthermore, $C R Y 1$ may be associated with a specific chronotype, but the effect of this polymorphism on diurnal preferences and the adaptation to work under different shift schedule, observed in the present study, requires further investigation within a larger population.

\section{Acknowledgments}

This project was supported by a grant from the PolishNorwegian Research Fund (PNRF 243-AI-1/07) and ECNIS2 (7PR/2011/266198). The authors declare no actual or potential competing financial interests.

\section{References}

1. Saksvik IB, Bjorvatn B, Hetland H, Sandal GM, Pallesen S. Individual differences in tolerance to shift work - A systematic review. Sleep Med Rev. 2011;15:221-35. http://dx.doi. org/10.1016/j.smrv.2010.07.002

2. Erren TC, Falaturi P, Morfeld P, Knauth P, Reiter RJ, Piekarski C. Shift work and cancer: the evidence and the challenge. Dtsch Arztebl Int. 2010;107:657-62.

3. Stevens RG, Hansen J, Costa G, Haus E, Kauppinen T, Aronson KJ, et al. Considerations of circadian impact for defining , shift work' in cancer studies: IARC Working Group Report. Occup Environ Med. 2011;68:154-62. http://dx.doi. org/10.1136/oem.2009.053512.

4. Stevens RG. Electric power use and breast cancer: a hypothesis. Am J Epidemiol. 1987;125:556-61.

5. Stevens RG. Circadian disruption and breast cancer: from melatonin to clock genes. Epidemiology. 2005;16:254-8. http://dx.doi.org/10.1097/01.ede.0000152525.21924.54.

6. DeBruyne JP, Hogenesch JB. A CRY in the night. Dev Cell. 2011;20:144-5. http://dx.doi.org/10.1016/j. devcel.2011.01.014

7. Hatanaka F, Matsubara C, Myung J, Yoritaka T, Kamimura $\mathrm{N}$, Tsutsumi S, et al. Genome-wide profiling of the core clock protein BMAL1 targets reveals a strict relationship with metabolism. Mol Cell Biol. 2010;30:5636-48. http://dx.doi. org/10.1128/MCB.00781-10.

8. Panda S, Antoch MP, Miller BH, Su AI, Schook AB, Straume $\mathrm{M}$, et al. Coordinated transcription of key pathways in the mouse by the circadian clock. Cell. 2002;109:307-20. http:// dx.doi.org/10.1016/S0092-8674(02)00722-5.

9. Ptitsyn AA, Zvonic S, Conrad SA, Scott LK, Mynatt RL, Gimble JM. Circadian clocks are resounding in peripheral tissues. PLoS Comput Biol. 2006;2:e16. http://dx.doi. org/10.1371/journal.pcbi.0020016.

10. Chen-Goodspeed M, Lee CC. Tumor suppression and circadian function. J Biol Rhythms. 2007;22:291-8. http:// dx.doi.org/10.1177/0748730407303387.

11. Lavebratt C, Sjöholm LK, Partonen T, Schalling M, Forsell Y. 
PER2 variantion is associated with depression vulnerability. Am J Med Genet B Neuropsychiatr Genet. 2010;153B:570-81.

12. Cuninkova L, Brown SA. Peripheral circadian oscillators: interesting mechanisms and powerful tools. Ann N Y Acad Sci. 2008;1129:358-70. http://dx.doi.org/10.1196/ annals.1417.005.

13. Haus E, Smolensky M. Biological clocks and shift work: circadian dysregulation and potential long-term effects. Cancer Causes Control. 2006;17:489-500. http://dx.doi.org/10.1007/ s10552-005-9015-4.

14. Marino JL, Holt VL, Chen C, Davis S. Shift work, hCLOCK T3111C polymorphism, and endometriosis risk. Epidemiology. 2008;19:477-84. http://dx.doi.org/10.1097/ EDE.0b013e31816b7378.

15. Sookoian S, Gianotti TF, Burgueño A, Pirola CJ. Gene-gene interaction between serotonin transporter (SLC6A4) and CLOCK modulates the risk of metabolic syndrome in rotating shiftworkers. Chronobiol Int. 2010;27:1202-18. http://dx.doi. org/10.3109/07420528.2010.496913.

16. Peplonska B, Bukowska A, Gromadzinska J, Sobala W, Reszka E, Lie J-A, et al. Night shift work characteristics and sulfatoksymelatonin (MT6s) in rotating night shift nurses and midwives. Occup Environ Med. 2012;69:339-46. http:// dx.doi.org/10.1136/oemed-2011-100273.

17. Buysse DJ, Reynolds CF 3rd, Monk TH, Berman SR, Kupfer DJ. The Pittsburgh Sleep Quality Index: a new instrument for psychiatric practice and research. Psychiatry Res. 1989;28:193-213. http://dx.doi.org/10.1016/01651781(89)90047-4.

18. Sherry ST, Ward MH, Kholodov M, Baker J, Phan L, Smigielski EM, et al. dbSNP: the NCBI database of genetic variation. Nucleic Acid Res. 2001;29:308-11. http://dx.doi. org/10.1093/nar/29.1.308.

19. Carpen JD, Archer SN, Skene DJ, Smits M, von Schantz M. A single-nucleotide polymorphism in the 5'-untranslated region of the hPER2 gene is associated with diurnal preference. J Sleep Res. 2005;14:293-7. http://dx.doi.org/10.1111/j.13652869.2005.00471.x.

20. Carpen JD, von Schantz M, Smits M, Skene DJ, Archer SN. A silent polymorphism in the PER1 gene associates with extreme diurnal preference in humans. J Hum Genet. 2006;51:1122-5. http://dx.doi.org/10.1007/s10038-006-0060-y.

21. Ebisawa T, Uchiyama M, Kajimura N, Mishima K, Kamei Y, Katoh M, et al. Association of structural polymorphisms in the human period3 gene with delayed sleep phase syndrome. EMBO Rep. 2001; 2:342-6. http://dx.doi.org/10.1093/emboreports/kve070.

22. Katzenberg D, Young T, Finn L, Lin L, King DP, Takahashi JS, et al. A CLOCK polymorphism associated with human diurnal preference. Sleep. 1998; 21:569-76.

23. Nievergelt CM, Kripke DF, Barrett TB, Burg E, Remick RA, Sadovnick AD, et al. Suggestive evidence for association of the circadian genes PERIOD3 and ARNTL with bipolar disorder. Am J Med Genet B Neuropsychiatr Genet. 2006;141B:234-41. http://dx.doi.org/10.1002/ajmg.b.30252.
24. Ukai-Tadenuma M, Yamada RG, Xu H, Ripperger JA, Liu AC, Ueda HR. Delay in feedback repression by cryptochrome 1 is required for circadian clock function. Cell. 2011;144:268-81. http://dx.doi.org/10.1016/j.cell.2010.12.019.

25. Nievergelt CM, Kripke DF, Remick RA, Sadovnick AD, McElroy SL, Keck PE Jr, et al. Examination of the clock gene Cryptochrome 1 in bipolar disorder: mutational analysis and absence of evidence for linkage or association. Psychiatr Genet. 2005;15:45-52. http://dx.doi.org/10.1097/00041444200503000-00008.

26. McCarthy MJ, Nievergelt CM, Shekhtman T, Kripke DF, Welsh DK, Kelsoe JR. Functional genetic variation in the RevErbo pathway and lithium response in the treatment of bipolar disorder. Genes Brain Behav. 2011;8:852-61. http://dx.doi. org/10.1111/j.1601-183X.2011.00725.x.

27. Mishima K, Tozawa T, Satoh K, Saitoh H, Mishima Y. The 3111T/C polymorphism of hClock is associated with evening preference and delayed sleep timing in a Japanese population sample. Am J Med Genet B Neuropsychiatr Genet. 2005;133B:101-4. http://dx.doi.org/10.1002/ajmg.b.30110.

28. Choub A, Mancuso M, Coppedè F, LoGerfo A, Orsucci D, Petrozzi L, et al. Clock T3111C and Per2 C111G SNPs do not influence circadian rhythmicity in healthy Italian population. Neurol Sci. 2011;32:89-93. http://dx.doi.org/10.1007/ s10072-010-0415-1.

29. Johansson C, Willeit M, Smedh C, Ekholm J, Paunio T, Kieseppä $\mathrm{T}$, et al. Circadian clock-related polymorphisms in seasonal affective disorder and their relevance to diurnal preference. Neuropsychopharmacol. 2003;28:734-9. http:// dx.doi.org/10.1038/sj.npp.1300121.

30. Katzenberg D, Young T, Lin L, Finn L, Mignot E. A human period gene (HPER1) polymorphism is not associated with diurnal preference in normal adults. Psychiatr Genet. 1999;9:107-9. http://dx.doi.org/10.1097/00041444-199906000-00011.

31. Partonen T, Treutlein J, Alpman A, Frank J, Johansson C, Depner M, et al. Three circadian clock genes Per2, Arntl, and Npas2 contribute to winter depression. Ann Med. 2007;39:229 38. http://dx.doi.org/10.1080/07853890701278795.

32. Sjöholm LK, Backlund L, Cheteh EH, Ek IR, Frisén L, Schalling M, et al. CRY2 is associated with rapid cycling in bipolar disorder patients. PLoS One. 2010;5:e12632. http:// dx.doi.org/10.1371/journal.pone.0012632.

33. Lavebratt C, Sjöholm LK, Soronen P, Paunio T, Vawter MP, Bunney WE, et al. CRY2 is associated with depression. PLoS One. 2010;5:e9407. http://dx.doi.org/10.1371/journal. pone.0009407.

34. Mansour HA, Wood J, Logue T, Chowdari KV, Dayal M, Kupfer DJ, et al. Association study of eight circadian genes with bipolar I disorder, schizoaffective disorder and schizophrenia. Genes Brain Behav. 2006;5:150-7. http:// dx.doi.org/10.1111/j.1601-183X.2005.00147.x.

Received for publication: 17 October 2011 